\title{
ANALISIS EFISIENSI PASAR MODAL SYARIAH DI INDONESIA
}

\author{
Yosi Stefhani \\ yosi.stefhani@yahoo.com
}

Jurusan Manajemen, Fakultas Ekonomi, Universitas Satya Negara Indonesia Jalan Arteri Pondok Indah No.11 Jakarta Selatan

\begin{abstract}
The purpose of this research to determine whether the Islamic capital market in Indonesia is efficient in semi-strong form. This research is event study research. The event that used in this research is announcement of changing composition on Jakarta Islamic Index (JII). The event windows that used in this research is ten days before $(H-10)$ and after $(H+10)$ the announcement of changing composition on JII. Data analysis techniques testing the hypothesis in this study using the Wilcoxon Signed Rank Test. The population used in this study is all of the shares that categorized in to the Jakarta Islamic Index (JII) in the period 2014 and 2015. The samples were taken by using purposive sampling method, and based on predetermined criteria then the samples were included in this study 120 shares. The research shows that there is no difference of abnormal return and average abnormal return before and after of the announcement The results of this study indicate that the Islamic capital market in Indonesia is efficient in semi-strong form.
\end{abstract}

Keywords: Islamic Capital Market, Jakarta Islamic Index, Abnormal Return

\section{PENDAHULUAN}

Perkembangan pasar modal syariah di Indoensia bisa dilihat dengan menggunakan indikator Indeks Saham Syariah Indonesia (ISSI) dan Jakarta Islam Indeks (JII). ISSI merupakan indeks saham yang mencerminkan keseluruhan saham syariah yang tercatat di BEI. Konstituen ISSI adalah keseluruhan saham syariah tercatat di BEI dan terdaftar dalam Daftar Efek Syariah (DES). Konstituen ISSI di review setiap 6 bulan sekali (Mei dan November) dan dipublikasikan pada awal bulan berikutnya. Konstituen ISSI juga dilakukan penyesuaian apabila ada saham syariah yang baru tercatat atau dihapuskan dari Daftar Efek Syariah (DES). Metode perhitungan indeks ISSI menggunakan rata-rata tertimbang dari kapitalisasi pasar. Tahun dasar yang digunakan dalam perhitungan ISSI adalah awal penerbitan DES yaitu Desember 2007. Indeks ISSI diluncurkan pada tanggal 12 Mei 2011. JII diluncurkan pada tanggal 3 Juli 2000. JII mengacu pada 30 saham yang sektor usahanya memenuhi prinsip Syariah Islam yang diatur dalam Fatwa DSN MUI Nomor 40/DSN-MUI/X/2002. Sesuai DSN Nomor 20/DSN-MUI/IV/2001 tentang Pedoman Pelaksanaan Investasi untuk Reksa Dana Syariah maka saham-saham yang masuk ke dalam JII harus memenuhi unsur yang sama dengan indeks lainnya kecuali unsur haram dalam pandangan MUI. Unsur haram yang disyaratkan DSN MUI pada umumnya 
terkait dengan kegiatan bisnis, yaitu tidak melakukan kegiatan bisnis yang terkait: Alkohol, Perjudian, Produksi dengan bahan baku babi, Pornografi, Jasa Keuangan dan Asuransi konvensional.

Perkembangan pasar modal syariah mengalami perkembangan setiap tahunnya. Koran Republika tanggal 4 November 2016 mencatat bahwa ISSI tumbuh paling tinggi dibanding dengan indeks saham syariah global. Dalam lima tahun terakhir ISSI tumbuh 43\%. Perkembangan kinerja pasar modal syariah dengan indikator ISSI dan JII dapat dilihat dari grafik di bawah ini.

Grafik 1

Perkembangan Kinerja JII dan ISSI

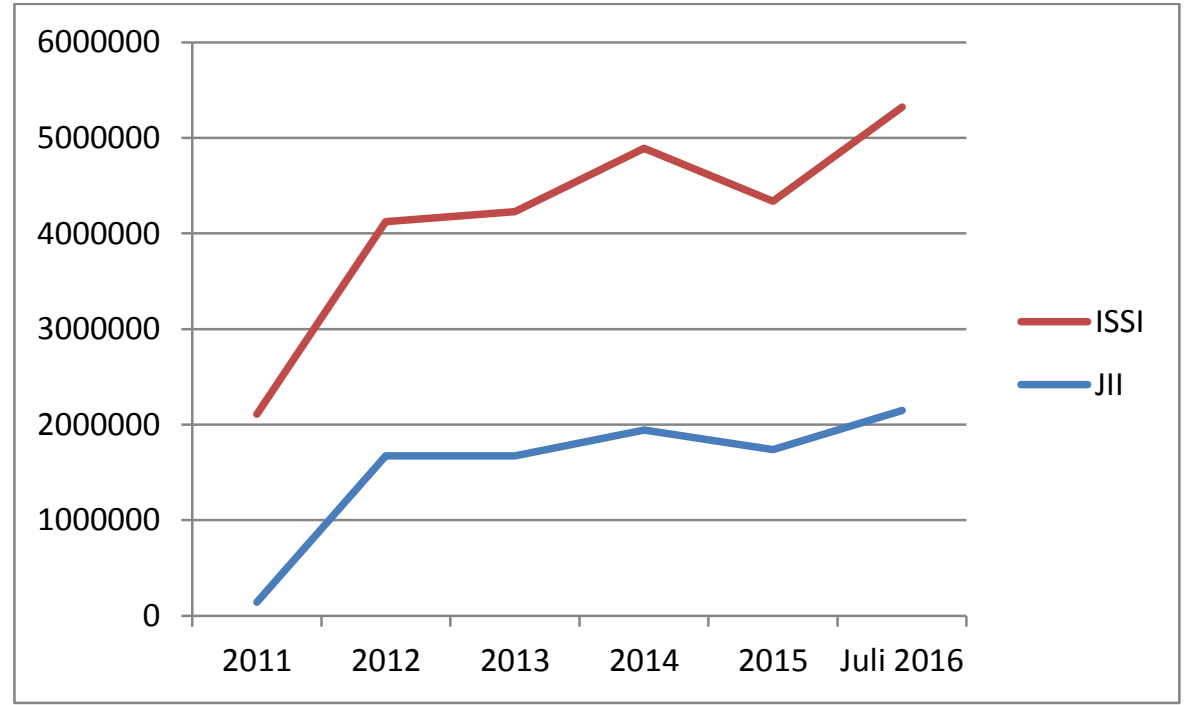

Sumber : Data OJK diolah Penulis

Dari grafik diatas terlihat bagaimana indeks ISSI dan JII memiliki tren yang ratarata meningkat setiap tahunnya. Kondisi ini menunjukan bagaimana pasar modal syariah di Indonesia memiliki potensi untuk terus meningkat setiap tahunnya. Kondisi ini didukung dengan mayoritas masyarakat Indonesia yang muslim.

Sama halnya dengan pasar modal konvensional, di pasar modal syariah efisiensi pasar juga diperhatikan. Pasar modal yang efisien berarti harga yang terbentuk di pasar modal tersebut mencerminkan semua informasi yang relevan. Pasar modal yang efisien sangat dibutuhkan untuk meredam tindakan spekulasi karena semua informasi menjadi dasar investor dalam pengambilan keputusan investasi. Spekulasi dilarang dalam Islam bukan karena ketidakpastian yang ada dihadapannya, melainkan cara orang menggunakan ketidakpastian tersebut. Itulah yang yang dilarang dalam konsep gharar dan maisyir dalam Islam. Merujuk pada fatwa DSN No.80/DSN-MUI/III/2011 tentang Penerapan Prinsip Syariah dalam Mekanisme Perdagangan Efek Bersifat Ekuitas di Pasar Reguler Bursa Efek Gharar adalah ketidakpastian dalam suatu akad, baik mengenai kualitas atau kuantitas obyek akad maupun mengenai penyerahannya. Sedangkan maisyir adalah suatu kegiatan bisnis yang di dalamnya jelas bersifat untung-untungan atau spekulasi yang tidak rasional, tidak logis, tak jelas barang yang ditawarkan baik secara kuantitatif maupun secara kualitatif. 
Untuk bisa memastikan bahwa transaksi di pasar modal syariah tidak mengandung unsur gharar dan maisyir yang di larang dalam prinsip syariah maka perlu dilakukan pengujian terkait transaksi pasar modal syariah melalui pengujian pasar modal syariah dengan menggunakan teori Hipotesis Pasar Efisien.

Menurut Weston \& Copeland efisiensi dalam pasar saham menunjukkan secara tidak langsung bahwa seluruh informasi relevan yang tersedia tentang suatu saham langsung tercermin dalam harganya. Oleh karena itu, pernyataan bahwa harga saham telah mencerminkan seluruh informasi yang tersedia disebut juga Hipotesis Pasar Efisien (Efficient Market Hypothesis-EMH)

Umumnya terdapat tiga versi EMH yaitu pertama Hipotesis Bentuk Lemah (WeakForm) menyebutkan bahwa harga saham telah mencerminkan seluruh informasi yang dapat diturunkan dengan menguji data perdagangan pasar berupa harga historis, volume perdagangan, dan bunga pinjaman. Kedua, Hipotesis Bentuk Semikuat (Semistrong-Form) menyebutkan bahwa seluruh informasi yang tersedia untuk publik tentang prospek suatu perusahaan seharusnya tercermin pada harga pasar saham, informasi tersebut meliputi harga masa lalu, data fundamental tentang lini produk perusahaan, kualitas manajemen, komposisi neraca, paten yang dipegang, prediksi laba, serta praktik akuntansi. Ketiga, Hipotesis Bentuk Kuat (Strong-Form) menyebutkan bahwa harga pasar mencerminkan seluruh informasi yang relevan bagi perusahaan, termasuk informasi yang hanya tersedia bagi orang dalam perusahaan. Dari ketiga bentuk efisiensi pasar di atas maka bentuk efisiensi yang sesuai dengan prinsip syariah adalah bentuk setengah kuat (semi strong form). Maka menjadi penting dilakukan adanya pengujian terkait efisiensi pasar modal syariah di Indonesia mengingat potensi yang besar dan bentuk efisiensi yang seharusnya terbentuk harus juga sesuai dengan prinsip syariah.

Penelitian sebelum yang pernah dilakukan diantaranya dilakukan oleh Suryadi Samudra pada tahun 2016, hasil penelitiannya menunjukan bahwa pasar modal syariah di Indonesia efisien dalam bentuk setengah kuat dengan dibuktikan dengan tidak adanya abnormal return yang diperoleh investor. Penelitian sebelumnya yang mempunyai hasil penelitian yang sama dilakukan oleh Mukmin pada tahun 2015 yang juga menunjukan bahwa pasar modal syariah di Indonesia efisien dalam bentuk setengah kuat. Sementara itu penelitian yang dilakukan oleh Ibnu Khajar pada tahun 2012 menunjukan bahwa pasar modal syariah di Indonesia efisien dalam bentuk lemah. Hasil penelitian ini didukung oleh hasil penelitian lainnya yang dilakukan oleh Ulfi Kartika Oktaviana pada tahun 2011 dimana hasil penelitiannya menunjukan pasar modal syariah di Indonesia tidak terbukti efisien dalam bentuk setengah kuat.

Maka berdasarkan penjelasan diatas dan diperkuat dengan penelitian-penelitian sebelumnya yang menunjukan hasil yang berbeda juga, penulis tertarik untuk melakukan penelitian dengan judul Analisis Efisiensi Pasar Modal Syariah di Indonesia.

\section{KERANGKA PEMIKIRAN TEORITIS}

Teori hipotesis pasar efisien (efficient market hypothesis) yang menyatakan bahwa harga saham mencerminkan seluruh informasi yang tersedia membedakannya menjadi 3 bentuk efficient market hypothesis. 
1. Hipotesis bentuk lemah (Weak Form). Hipotesis ini menyatakan bahwa harga saham mencerminkan seluruh informasi yang dapat diturunkan dengan menguji data perdagangan pasar seperti data harga terdahulu, volume penjualan dll.

2. Hipotesis bentuk setengah kuat (Semi Strong Form). Hipotesis ini menyatakan bahwa harga saham mencerminkan seluruh informasi yang tersedia untuk publik tentang prospek suatu perusahaan seperti data terdahulu, data fundamental dll.

3. Hipotesis bentuk kuat (Strong Form). Hipotesis ini menyatakan bahwa harga saham mencerminkan seluruh informasi yang relevan dengan perusahaan termasuk informasi yang hanya diketahui oleh orang dalam perusahaan.

Dari ketiga bentuk efisiensi pasar modal diatas bentuk pasar modal syariah seharusnya merupakan bentuk efisiensi pasar bentuk setengah kuat. Bentuk ini yang paling sesuai dengan pasar modal syariah karena sesuai dengan prinsip syariah. Alasan bentuk lain tidak sesuai dengan prinsip syariah adalah sebagai berikut :

1. Hipotesis bentuk lemah (Weak Form). Hipotesis ini menyatakan bahwa harga saham hanya mencerminkan historical data terkait harga saham, volume penjualan dll. Sementara itu data terkini terkait dengan perusahaan yang menerbitkan saham tidak tercermin. Harga saham masa lalu belum tentu tercermin pada harga di masa yang akan datang. Karena bisa jadi informasi terkini terkait saham tersebut mampu menyebabkan permintaan naik atau turun. Kenaikan atau penurunan permintaan akan saham tersebut mampu mempengaruhi harga. Jika hanya harga dan volume perdagangan terdahulu saham tersebut sebagai acuan harga saham di masa yang akan datang membuat potensi besar unsur gharar dan masyir muncul.

2. Hipotesis bentuk kuat (Strong Form). Hipotesis ini menyatakan bahwa harga saham mencerminkan semua informasi publik yang tersedia juga termasuk informasi yang dimiliki oleh orang dalam. Kondisi ini bisa memicu terjadinya perdagangan orang dalam (insider trading) yang jelas-jelas tindakan ini tidak sesuai prinsip syariah dan dilarang merujuk pada fatwa DSN No.80/DSN-MUI/III/2011 tentang Penerapan Prinsip Syariah dalam Mekanisme Perdagangan Efek Bersifat Ekuitas di Pasar Reguler Bursa Efek.

Beberapa penelitian terdahulu terkait bentuk efisiensi pasar modal syariah di Indonesia telah dilakukan diantaranya yaitu :

1. Penelitian yang dilakukan oleh Suryadi Samudra pada tahun 2016. Sampel penelitiannya saham-saham yang termasuk ke dalam JII periode Desember 2013 sampai dengan November 2014. Event study yang digunakan adalah pengumuman deviden. Hasil penelitiannya menunjukan bahwa pasar modal syariah di Indonesia efisien dalam bentuk setengah kuat.

2. Penelitian yang dilakukan oleh Mukmin pada tahun 2015. Sampel penelitiannya saham-saham yang termasuk ke dalam JII periode Juni 2011 sampai dengan Desember 2014. Event study yang digunakan adalah pengumuman komposisi JII. Hasil penelitian menunjukan bahwa pasar modal syariah di Indonesia efisien dalam bentuk setengah kuat.

3. Penelitian yang dilakukan oleh Ibnu Khajar pada tahun 2012. Sampel penelitiannya 6 saham yang termasuk ke dalam JII tahun 2008. Event study yang digunakan adalah 
krisis finansial global tahun 2008. Hasil penelitan menunjukan bahwa pasar modal syariah di Indonesia efisien dalam bentuk lemah.

4. Penelitian lainnya yang dilakukan oleh Ulfi Kartika Oktaviana pada tahun 2011. sampel penelitiannya adalah saham yang termasuk JII periode 2004-2010. Event Study yang digunakan adalah pengumuman komposisi JII. Hasil penelitiannya menunjukan pasar modal syariah di Indonesia tidak terbukti efisien dalam bentuk setengah kuat. Berdasarkan penjelasan diatas dan penelitian terdahulu yang relevan maka disusun kerangka pemikiran dalam penelitian ini sebagai berikut:

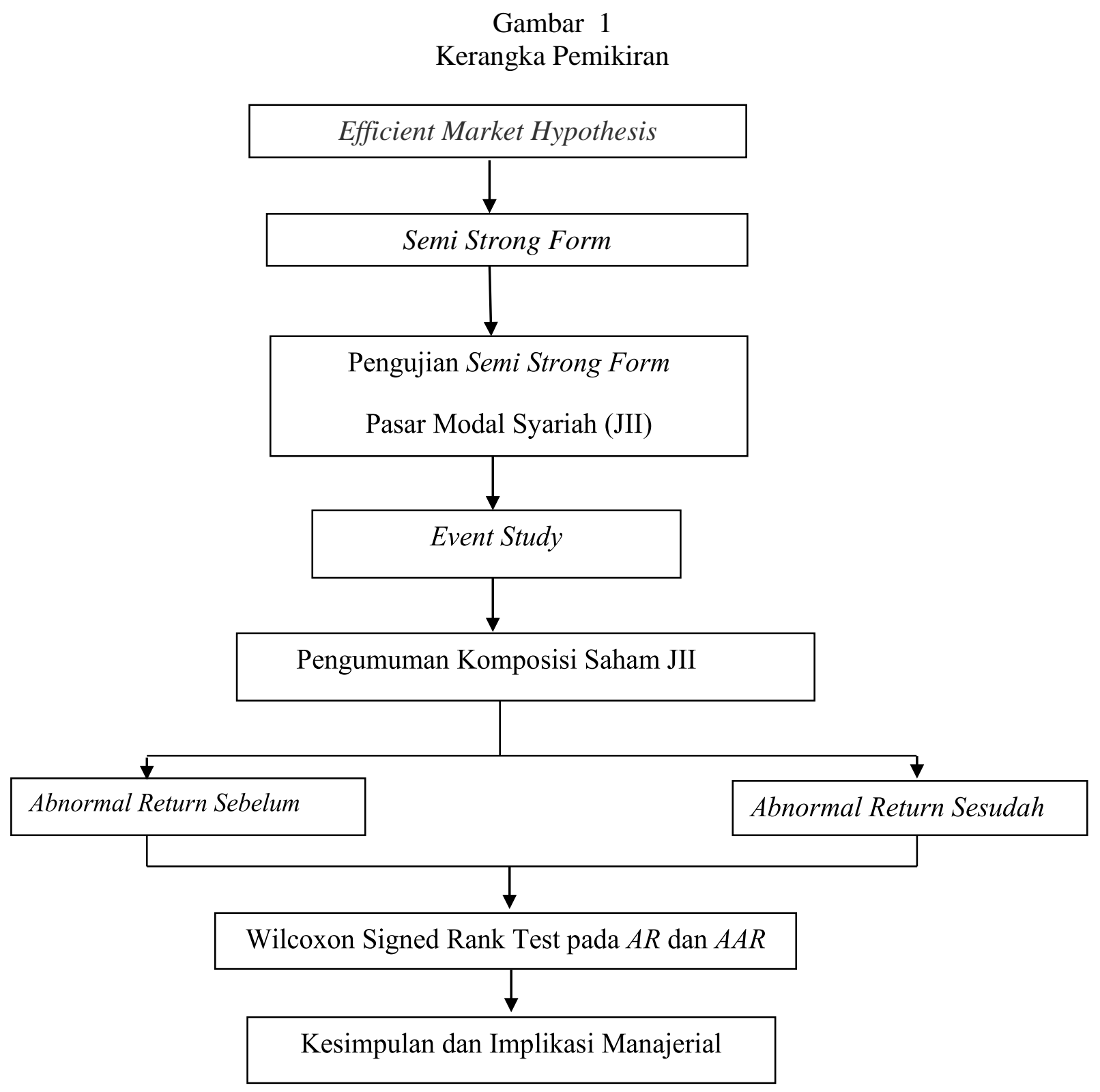

Sumber : Diolah Penulis 
Hipotesis yang diajukan dalam penelitian ini adalah :

Hipotesis 1:

Ho : Tidak terdapat perbedaan abnormal return JII sebelum dan sesudah pengumuman komposisi JII

Ha : Terdapat perbedaan abnormal return JII sebelum dan sesudah pengumuman komposisi JII

Hipotesis 2:

Ho : Tidak terdapat perbedaan average abnormal return JII sebelum dan sesudah pengumuman komposisi JII

Ha : Terdapat perbedaan average abnormal return JII sebelum dan sesudah pengumuman komposisi JII

\section{METODE}

\section{Populasi dan Sampel}

Populasi pada penelitian ini adalah seluruh saham emiten yang terdaftar di Jakarta Islamic Index (JII) serta saham yang dimasukkan dari indeks tersebut selama periode 2014 hingga 2015. Teknik sampling yang digunakan pada penelitian ini adalah teknik sampling berdasarkan kriteria (purposive sampling). Kriteria yang digunakan untuk pemilihan sampel pada penelitian ini adalah :

1. Saham emiten masuk ke dalam pengumuman perubahan komposisi saham Jakarta Islamic Index

2. Saham emiten aktif diperdagangkan selama periode window period

3. Emiten tidak melakukan corporate action apapun selama periode window period

Alasan penggunaan kriteria tersebut adalah untuk menghindari data yang dapat menyebabkan bias pada saat dilakukan analisis data.

\section{Desain Penelitian}

Desain penelitian yang digunakan yaitu event study. Event study adalah penelitian yang mempelajari reaksi pasar terhadap suatu peristiwa (event) yang informasinya dipublikasikan sebagai pengumuman. Event yang digunakan pada penelitian ini adalah pengumuman perubahan komposisi saham dalam perhitungan Jakarta Islamic Index. Periode pengamatan (Window Period) dalam penelitian ini adalah selama 20 hari pengamatan dimana $\mathbf{1 0}$ hari sebelum Pengumuman Jakarta Islamic Index dan 10 hari sesudah Pengumuman Jakarta Islamic Index.

\section{Jenis dan Sumber Data}

Penelitian ini menggunakan data sekunder. Data sekunder adalah data yang tersedia atau sudah terkumpul. Sumber data yang diperoleh dengan cara membaca, mempelajari dan memahami melalui media lain yang bersumber dari literatur, buku-buku, serta dokumen perusahaan. Data sekunder yang di gunakan pada penelitian ini diperoleh OJK dan www.yahoo.finance.com. 


\section{Definisi Operasional Variabel dan Skala Pengukurannya}

Dalam penelitian ini variabel yang digunakan adalah Abnormal Return, Average Abnormal Return dan Cumulative Average Abnormal Return . Abnormal return merupakan kelebihan dari imbal hasil yang sesungguhnya terjadi (actual return) terhadap imbal hasilnormal. Imbal hasil normal merupakan imbal hasil ekspektasi (expected return) atau imbal hasil yang diharapkan oleh investor. Dengan demikian imbal hasil tidak normal (abnormal return) adalah selisih antara imbal hasil realisasi dengan imbal hasil ekspektasi.

Abnormal return dapat dihitung dengan menggunakan rumus sebagai berikut :

$$
A R_{i t}=R_{i t}-\mathbf{E}\left(R_{i t}\right)
$$

Dimana :

$\mathrm{AR}_{\mathrm{it}} \quad$ : Abnormal return saham i hari ke $\mathrm{t}$

$\mathrm{R}_{\mathrm{it}} \quad$ : Actual return / return realisasi saham i hari ke $\mathrm{t}$

$\mathrm{E}\left(\mathrm{R}_{\mathrm{it}}\right)$ : Expected return saham i hari ke $\mathrm{t}$ berikut :

Sementara itu langkah-langkah dalam menghitung abnormal return adalah sebagai

1) Menghitung Return Realisasi (Actual Return)

Return realisasi (realized return) merupakan return yang telah terjadi. Return realisasi dihitung menggunakan data historis. Return realisasi penting karena digunakan sebagai salah satu pengukur kinerja dari perusahaan. Return realisasi berguna sebagai dasar penentuan (expected return ) dan risiko di masa mendatang. Return realisasi dapat dihitung dengan menggunakan rumus sebagai berikut :

$$
R_{t}=\frac{P_{i t}-P_{i t-1}}{P_{i t-1}}
$$

Dimana :

$\mathrm{R}$ _it $\quad$ : Return saham pada periode $\mathrm{t}$

$\mathrm{P} \_$it $\quad$ : Harga atau nilai pada akhir periode $\mathrm{t}$

P_(it-1):Harga atau nilai pada periode sebelumnya (t-1)

2) Menghitung Return Ekspektasi (Expected Return)

$$
E(R i, t)=\frac{\sum_{j=t 1}^{t 2} \mathrm{Rij}}{\mathrm{T}}
$$

Dimana :

$E\left(R_{i}, t\right)=$ Return Ekspetasi sekuritas ke-i pada periode estimasi ke-t

$\mathrm{R}_{\mathrm{ij}} \quad=$ Return Realisasi sekuritas ke-i pada periode estimasi ke- $\mathrm{j}$

$\mathrm{T}$ = lamanya periode estimasi yaitu dari $\mathrm{t} 1$ sampai dengan $\mathrm{t} 2$

Average abnormal return merupakan rata-rata abnormal return $(A R)$ dari semua jenis saham yang sedang dianalisis secara harian. Average abnormal return dapat menunjukkan reaksi paling kuat, baik positif maupun negatif, dari keseluruhan jenis saham selama 
window period. Average Abnormal Return dapat dihitung dengan menggunakan rumus sebagai berikut :

$$
\text { AARt }=\frac{\frac{\sum_{i=1}^{N} A R i t}{N}}{N}
$$

Dimana :

$\mathrm{AAR}_{\mathrm{t}}$ : Rata-rata abnormal return pada hari ke $\mathrm{t}$

$\mathrm{AR}_{\mathrm{it}}$ : Abnormal return saham i hari ke $\mathrm{t}$

$\mathrm{N} \quad$ : Jumlah saham yang terpengaruh pengumuman

\section{Teknik Analisis Data}

Pengujian uji beda yang akan dilakukan dalam penelitian ini bisa menggunakan statistic parametrik atau statistic non parametrik tergantung kemudiang dari data penelitian yang digunakan apakah terdistribusi normal atau tidak. Berikut uji beda yang dapat digunakan :

1. Uji Paired Sample t-Test atau uji T sampel berpasangan merupakan uji parametrik yang digunakan untuk menguji apakah ada perbedaan rata-rata dua sampel yang berhubungan.uji ini digunakan jika data penenitian terdistribusi dengan normal.

2. Uji Wilcoxon Signed Rank Test merupakan uji non parametrik yang digunakan untuk menganalisis data berpasangan karena adanya dua perlakuan yang berbeda. Wilcoxon Signed Rank Test digunakan apabila data tidak berdistribusi normal dan ini terlihat setelah dilakukan uji normalitas data dengan uji Kolmogorov Smirnov.

Untuk pengambilan keputusan dalam penelitian ini pertimbangan yang dilakukan, sebagai berikut :

1. Jika probabilitas $<0,05$, maka $\mathrm{H}_{0}$ ditolak.

2. Jika probabilitas $>0,05$, maka $\mathrm{H}_{0}$ diterima.

\section{PEMBAHASAN}

Penelitian ini termasuk ke dalam penelitian event study. Event study adalah penelitian yang mempelajari reaksi pasar terhadap suatu peristiwa (event) yang informasinya dipublikasikan sebagai pengumuman. Event yang digunakan pada penelitian ini adalah pengumuman perubahan komposisi saham dalam penghitungan Jakarta Islamic Index. Periode pengamatan (Window Period) dalam penelitian ini adalah selama 20 hari pengamatan dimana $\mathbf{1 0}$ hari sebelum pengumuman dan 10 hari sesudah Pengumuman. Variabel yang menjadi objek penelitian adalah abnormal return dan average abnormal return saham sebelum dan sesudah pengumuman perubahan komposisi saham dalam penghitungan Jakarta Islamic Index. Selama periode 2014 dan 2015 maka terdapat 4 periode pengumuman. Berikut ini merupakan average abnormal return sebelum pengumuman selama periode penelitian mulai dari $\mathrm{H}-10$ sampai dengan $\mathrm{H}-$ 1 . 
Gambar 2

Average Abnormal Return Sebelum Pengumuman

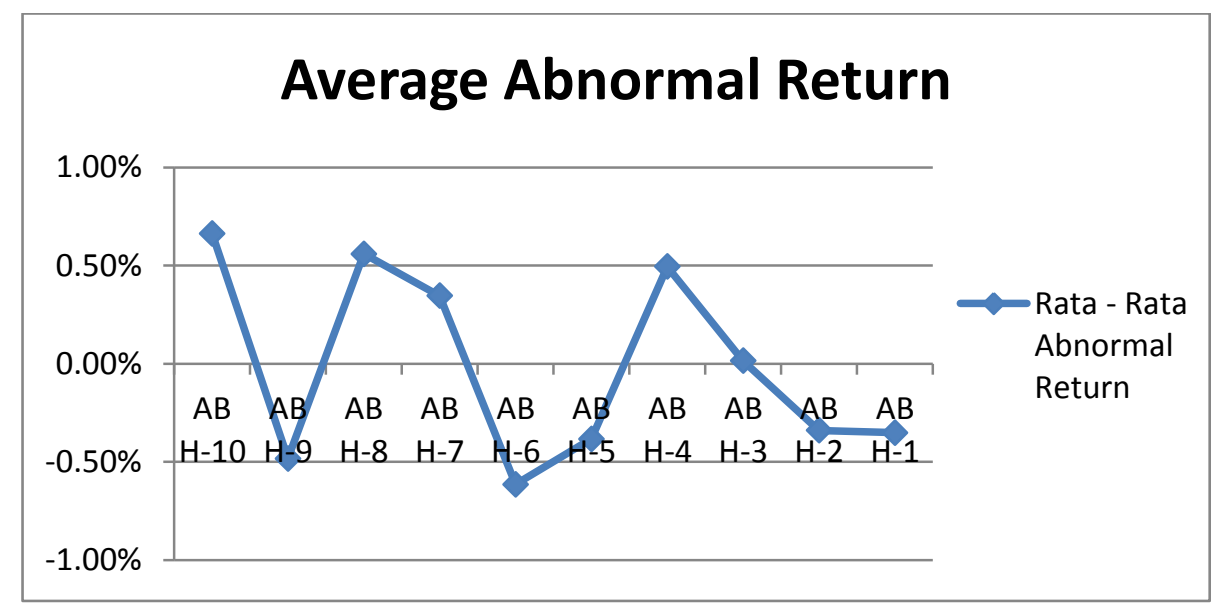

Sumber: Data Diolah Peneliti

Dari data di atas terlihat average abnormal return sebelum pengumuman dari $\mathrm{H}-10$ sampai dengan $\mathrm{H}-1$ berkisar antara kurang dari $1 \%$ sampai dengan kurang dari $-1 \%$. Interprestasi untuk average abnormal return yang bernilai- berarti expected return lebih besar dibandingkan actual return. Expected return (tingkat pengembalian yang diharapkan oleh investor) terlalu tinggi dibandingkan actual return (tingkat pengembalian riil yang terjadi) kondisi inilah yang menyebabkan abnormal return menjadi negatif sehingga menyebabkan average abnormal return negatif. Average abnormal return yang bernilai negatif terjadi di $\mathrm{H}-9, \mathrm{H}-6, \mathrm{H}-5, \mathrm{H}-2$ dan $\mathrm{H}-1$. Average abnormal return terendah (yang mendekati 0) terjadi di $\mathrm{H}-3$ sebesar $0,02 \%$.

Sementara itu berikut data average abnormal return sesudah pengumuman selama periode penelitian mulai dari $\mathrm{H}+1$ sampai dengan $\mathrm{H}+10$.

Gambar 3

Average Abnormal Return Sesudah Pengumuman

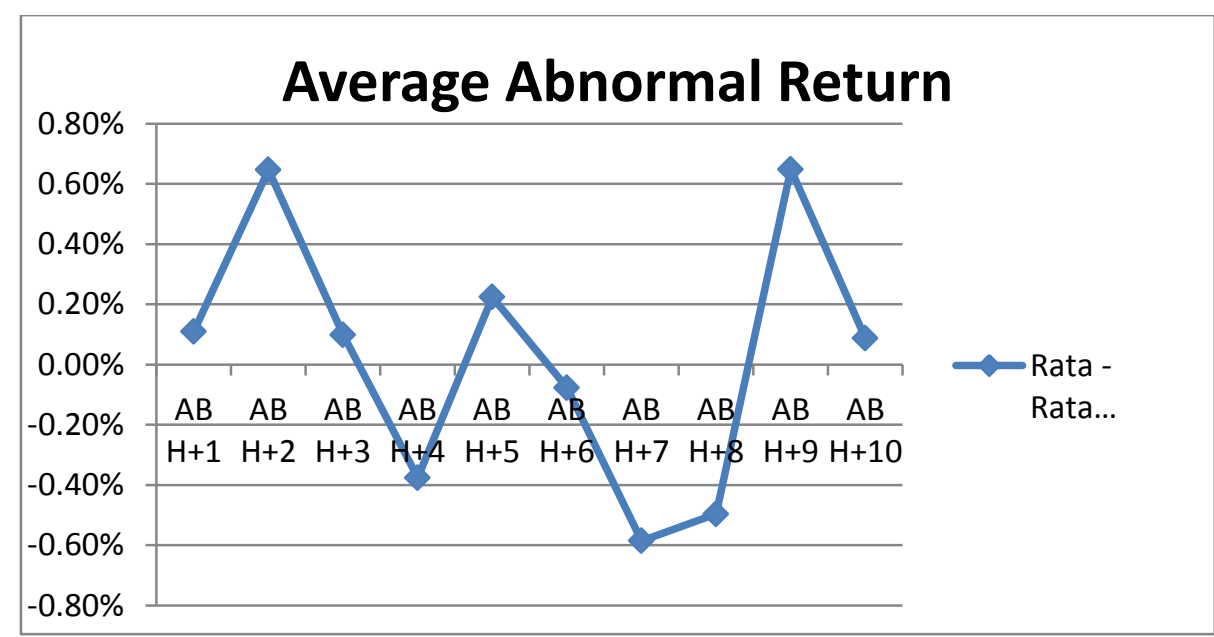

Sumber: Data Diolah Peneliti 
Dari data di atas terlihat average abnormal return sesudah pengumuman dari $\mathrm{H}+1$ sampai dengan $\mathrm{H}+10$ berkisar antara kurang dari $1 \%$ sampai dengan kurang dari $-1 \%$. Interprestasi untuk average abnormal return yang bernilai- berarti expected return lebih besar dibandingkan actual return. Expected return (tingkat pengembalian yang diharapkan oleh investor) terlalu tinggi dibandingkan actual return (tingkat pengembalian riil yang terjadi) kondisi inilah yang menyebabkan abnormal return menjadi negatif sehingga menyebabkan average abnormal return negatif. Average abnormal return yang bernilai negatif terjadi di $\mathrm{H}+4, \mathrm{H}+6, \mathrm{H}+7$, dan $\mathrm{H}+8$. Average abnormal return terendah (yang mendekati 0) terjadi di $\mathrm{H}+10$ sebesar 0,09\%.

Teknik analisis data dalam pengujian hipotesis di penelitian ini menggunakan Wilcoxon Signed Rank Test. Uji menggunakan teknik analisis data ini digunakan mengingat data dalam penelitian ini tidak terdistribusi normal. Wilcoxon Signed Rank Test merupakan salah satu teknik analisis data dalam non parametrik yang merupakan pengujian untuk melihat perbedaan data yang berpasangan. Pengujian hipotesis uji beda ini dilakukan dengan membandingkan data sebelum dan sesudah pengumuman selama periode pengamatan.

Pengujian uji beda antara data sebelum dan sesudah pengumuman dimulai dari pengujian uji beda abnormal return sebelum dan sesudah pengumuman mulai dari $\mathrm{H}-10$ dan $\mathrm{H}+10$ sampai dengan $\mathrm{H}-1$ dan $\mathrm{H}+1$.

Adapun hipotesis yang diajukan adalah sebagai berikut :

Ho : Tidak terdapat perbedaan abnormal return JII sebelum $(\mathrm{H}-)$ dan sesudah $(\mathrm{H}+)$ pengumuman komposisi JII

Ha : Terdapat perbedaan abnormal return JII sebelum $(\mathrm{H}-)$ dan sesudah $(\mathrm{H}+)$ pengumuman komposisi JII

Berikut hasil pengujian uji beda abnormal return sebelum dan sesudah pengumuman mulai dari $\mathrm{H}-10$ dan $\mathrm{H}+10$ sampai dengan $\mathrm{H}-1$ dan $\mathrm{H}+1$.

Tabel 1

Hasil Uji Beda Abnormal Return Selama Periode Pengamatan

\begin{tabular}{|c|c|c|c|}
\hline No & Periode Pengamatan & Hasil Uji Beda & Analisa \\
\hline 1. & $\begin{array}{l}\text { Abnormal Return } \mathrm{H}-10 \text { dan } \\
\mathrm{H}+10\end{array}$ & $\begin{array}{l}\text { Tidak Terdapat } \\
\text { Perbedaan }\end{array}$ & \multirow{9}{*}{$\begin{array}{lr}\text { Berdasarkan } & \text { hasil } \\
\text { pengujian selama } \\
\text { periode pengamatan } \\
\text { maka dapat terlihat } \\
\text { bahwa perbedaan } \\
\text { abnormal return } \\
\text { sebelum } \\
\text { sesudah yang tidak } \\
\text { konsisten } \\
\text { menjelang dan } \\
\text { pengumuman }(\mathbf{H}-3 \\
\text { s/d H-1) terlihat }\end{array}$} \\
\hline 2. & Abnormal Return H-9 dan $\mathrm{H}+9$ & Terdapat Perbedaan & \\
\hline 3. & Abnormal Return $\mathrm{H}-8$ dan $\mathrm{H}+8$ & Terdapat Perbedaan & \\
\hline 4. & Abnormal Return H-7 dan $\mathrm{H}+7$ & Terdapat Perbedaan & \\
\hline 5. & Abnormal Return H-6 dan H+6 & Terdapat Perbedaan & \\
\hline 6. & Abnormal Return $\mathrm{H}-5$ dan $\mathrm{H}+5$ & Terdapat Perbedaan & \\
\hline 7. & Abnormal Return $\mathrm{H}-4$ dan $\mathrm{H}+4$ & Terdapat Perbedaan & \\
\hline 8. & Abnormal Return $\mathrm{H}-3$ dan $\mathrm{H}+3$ & $\begin{array}{l}\text { Tidak Terdapat } \\
\text { Perbedaan }\end{array}$ & \\
\hline 9. & Abnormal Return $\mathrm{H}-2$ dan $\mathrm{H}+2$ & $\begin{array}{l}\text { Tidak Terdapat } \\
\text { Perbedaan }\end{array}$ & \\
\hline
\end{tabular}




\begin{tabular}{|c|l|l|l|}
\hline 10. & Abnormal Return $\mathrm{H}-1$ dan $\mathrm{H}+1$ & $\begin{array}{l}\text { Tidak Terdapat } \\
\text { Perbedaan }\end{array}$ & $\begin{array}{l}\text { justru tidak dapat } \\
\text { perbedaan } \\
\text { abnormalreturn } \\
\text { sebelum dan sesudah } \\
\text { menunjukan bahwa } \\
\text { pasar rodal modal } \\
\text { syariah efisien } \\
\text { dalam bentuk } \\
\text { setengah kuat. }\end{array}$ \\
\hline
\end{tabular}

Pengujian uji beda selain menguji abnormal return harian sebelum dan sesudahnya juga dilakukan pengujian uji beda average abnormal return. Adapun hipotesis yang diajukan adalah sebagai berikut :

Ho : Tidak terdapat perbedaan average abnormal return JII sebelum (H-) dan sesudah $(\mathrm{H}+)$ pengumuman komposisi JII

Ha : Terdapat perbedaan average abnormal return JII sebelum (H-) dan sesudah $(\mathrm{H}+)$ pengumuman komposisi JII

Hasil uji beda average abnormal return sebelum dan sesudah pengumuman adalah sebagai berikut :

Tabel 2

Hasil Uji Beda AAR Sebelum dan Sesudah

Test Statistics ${ }^{\mathrm{a}}$

\begin{tabular}{|l|r|}
\hline & \multicolumn{2}{|c|}{$\begin{array}{c}\text { AAR SESUDAH - } \\
\text { AAR SEBELUM }\end{array}$} \\
\hline $\mathrm{Z}$ & $-.153^{\mathrm{b}}$ \\
$\begin{array}{l}\text { Asymp. Sig. (2- } \\
\text { tailed) }\end{array}$ & .878 \\
\hline
\end{tabular}

a. Wilcoxon Signed Ranks Test

b. Based on negative ranks.

Sumber : Output SPSS

Tabel diatas menunjukan hasil pengolahan data variabel average abnormal return seluruh saham sebelum dan sesudah pengumuman perubahan komposisi saham Jakarta Islamic Index (JII) selama periode penelitian. Dari hasil pengolahan data menunjukkan bahwa tidak terdapat perbedaan average abnormal return saham sebelum dan sesudah pengumuman perubahan komposisi saham Jakarta Islamic Index (JII), dimana nilai signifikan sebesar 0,878 lebih besar dari 0,05. Hal ini berarti $\mathrm{H}_{0}$ diterima sedangkan $\mathrm{H}_{\mathrm{a}}$ ditolak.

Berdasarkan hasil pengolahan data menunjukan selama periode pengamatan perbedaan abnormal return sebelum dan sesudah pengumuman perubahan komposisi saham JII tidak konsisten. Dari pengujian 10 periode maka tidak terdapat perbedaan abnormal return sebelum dan sesudah terjadi pada periode pengamatan $\mathrm{H}-10$ dan $\mathrm{H}+10, \mathrm{H}-$ 3 dan $\mathrm{H}+3, \mathrm{H}-2$ dan $\mathrm{H}+2, \mathrm{H}-1$ dan $\mathrm{H}+1$. Sementara itu sisa periode pengamatan lainnya 
menunjukan adanya perbedaan abnormal return. Berikut merupakan hasil uji beda abnormal return sebelum dan sesudah pengumuman perubahan komposisi saham JII.

Sesuai dengan konsep pasar modal efisien oleh Fama, suatu pasar dikatakan efisien bila investor tidak mampu untuk mendapatkan abnormal return secara konsisten. Selain itu, pasar juga akan dengan cepat menyesuaikan harga saham ke titik keseimbangan yang baru sehingga abnormal return yang diperoleh akan terserap dengan cepat oleh pasar. Maka berdasarkan hasil uji beda abnormal return selama periode pengamatan menunjukan tidak terdapat perbedaan abnormal return sebelum dan sesudah secara konsisten.

Dari hasil pengujian menunjukan menjelang pengumuman yaitu mulai $\mathrm{H}-3$ sampai dengan $\mathrm{H}-1$ (sebelum pengumuman) dan mulai dari $\mathrm{H}+1$ sampai dengan $\mathrm{H}+3$ (sesudah pengumuman) secara konsisten menunjukan tidak terdapat perbedaan abnormal return. Ini berarti informasi yang didapatkan oleh investor sama selama periode tersebut dan direspon dengan reaksi sama oleh investor. Informasi dan respon yang sama ini yang menyebabkan tidak terdapatnya perbedaan abnormal return sebelum (H-3 sampai dengan $\mathrm{H}-1)$ dan sesudah $(\mathrm{H}+1$ sampai dengan $\mathrm{H}+3)$.

Sementara itu hasil uji beda average abnormal return juga menunjukan tidak terdapat perbedaan abnormal return. Maka berdasarkan hasil pengujian menunjukan bahwa pasar modal syariah di Indonesia dengan menggunakan indikator JII merupakan pasar modal yang efisien dalam bentuk setengah kuat (Semi Strong Form).

Hasil penelitian yang menunjukan bahwa pasar modal syariah di Indonesia merupakan pasar modal yang efisien dalam bentuk setengah kuat maka jika dibandingkan dengan 4 penelitian sebelumnya yang relevan maka hasil penelitian ini konsisten dengan hasil penelitian yang dilakukan oleh Suryadi Samudra tahun 2016 dan penelitian yang dilakukan oleh Mukmin tahun 2015. Tapi hasil penelitian ini tidak konsisten dengan hasil penelitian yang dilakukan oleh Ibnu Khajar tahun 2012 dan Ulfi Kartika tahun 2011.

Berikut ringkasan perbandingan hasil penelitian dengan penelitian sebelumnya yang relevan yang dijadikan rujukan dalam penelitian ini.

Tabel 3

Perbandingan

Hasil Penelitian dengan Penelitian Sebelumnya yang Relevan

\begin{tabular}{|c|c|c|}
\hline Hasil Penelitian & \multicolumn{2}{|c|}{ Penelitian Sebelumnya } \\
\hline & Konsisten & $\begin{array}{l}\text { Tidak Konsisten } \\
\end{array}$ \\
\hline $\begin{array}{lr}\text { Tidak terdapat perbedaan } \\
\text { average abnormal } & \text { return. } \\
\text { sebelum dan } & \text { sesudah } \\
\text { pengumuman, } & \text { ini } \\
\text { menunjukan bahwa pasar } \\
\text { modal syariah efisien dalam } \\
\text { bentuk setengah kuat }\end{array}$ & $\begin{array}{ll}\text { 1. } & \text { Suryadi Samudra } \\
& (2016) \\
\text { 2. } & \text { Mukmin (2015) }\end{array}$ & 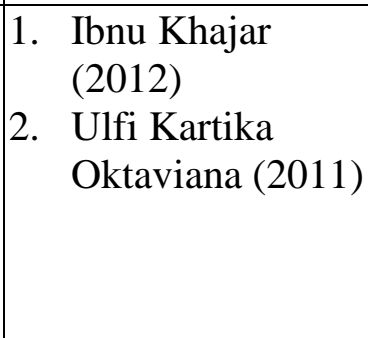 \\
\hline
\end{tabular}

Sumber : Diolah Penulis 


\section{PENUTUP}

Berdasarkan hasil pengujian dan pembahasan maka kesimpulan yang bisa diambil sebagai jawaban dari perumusan masalah dalam penelitian ini bahwa selama periode pengamatan maka dapat terlihat perbedaan abnormal return sebelum dan sesudah yang tidak konsisten dan menjelang pengumuman (H-3 s/d H-1) terlihat justru tidak dapat perbedaan abnormalreturn sebelum dan sesudah menunjukan bahwa pasar modal syariah efisien dalam bentuk setengah kuat. Berdasarkan proses penelitian yang dilakukan dan hasil penelitian ini maka penulis merekomendasikan berbagai hal untuk berbagai pihak yang terkait dengan pasar modal syariah yang efisien.

1. Bagi kepentingan penelitian selanjutnya

Untuk memperkuat bukti pasar modal syariah di Indonesia efisien dalam bentuk setengah kuat perlu dilakukan penelitian selanjutnya dengan menggunakan event study lain seperti pengumuman deviden atau yang lainnya.

2. Bagi perusahaan

Bagi perusahaan yang sahamnya termasuk Jakarta Islamic Index hasil penelitian menunjukan peristiwa pengumuman perubahan komposisi JII direspon oleh investor sehingga perusahaan berusaha untuk mempertahankan tetap termasuk dalam saham JII.

3. Bagi Regulator

Selama ini pembahasan tentang pasar modal syariah hanya fokus dengan saham-saham yang sesuai dengan kriteria saham syariah dan jenis-jenis transaksinya, hasil penelitian menunjukan bahwa return yang diperoleh berdasarkan mekanisme pasar juga harus sesuai dengan prinsip syariah sehingga perlu dibuat regulasi pengawasan tentang hal ini.

\section{DAFTAR PUSTAKA}

Aldila Vania Jasmine. 2015. "Reaksi Pasar Atas Stock Split Pada Emiten Saham Syariah Di Bursa Efek Indonesia Periode 2011-2014”. JESTT Vol. 2 No. 8. 2015.

Bodie, Zvi, Alex Kane and Alan J. Marcus . 2011. Investments, Global Edition, New York: The McGraw-Hill Companies,Inc.

Darmadji, Tjiptono dan Fakhrudin. 2011. Pasar Modal di Indonesia. Edisi Ketiga. Jakarta : Salemba Empat.

Firga Yanti. 2012. "Pengujian Abnormal Return Saham Sebelum Dan Sesudah Peluncuran Indeks Saham Syariah Indonesia (ISSI)”. Jurnal Manajemen. Vol 1. No 1.2012

Heykal, Mohamad. 2012. "Tuntunan dan Aplikasi Investasi Syariah". Elex'Media Komputindo, Jakarta. Cetakan Pertama, Jakarta.

Jogiyanto, Hartono, 2013. "Teori Portofolio dan Analisis Investasi", BPFE Yogyakarta, Edisi Kedelapan, Yogyakarta.

Khajar, Ibnu. 2012. " Efisiensi Pasar Modal Syariah Indonesia Sebelum dan Sesudah Krisis Finansial Global 2008". Jurnal Keuangan dan Perbankan Vol 16, No.1, Januari 2012, Hal 66-76.

Mukmin. 2015. "Efisiensi Pasar Saham Syariah di Indonesia Berdasarkan Pengumuman Perubahan Komposisi Saham di Jakarta Islamic Index (JII)". Jurnal Sosial Humaniora. Vol 6. No 1. 2015. 
Oktaviana, Ulfi Kartika dan Nanik Wahyuni. 2011. "Pengaruh Perubahan Komposisi Jakarta Islamic index (JII) terhadap Return Saham “. Jurnal el-QUDWAH Vol 1, No.5 Edisi April, 2011.

Priyatno, Dwi 2014.” SPSS 22 : Pengolahan Data Terpraktis “. ANDI Yogyakarta, Edisi satu, Yogyakarta.

Rivai, Veithzal, Amiur Nuruddin dan Faisar Ananda 2012. "Islamic Business and economic Ethics". Bumi Aksara Jakarta. Cetakan Pertama, Jakarta.

Suryadi Samudera, Muslimin, dan Husnah. 2016. "Analisis Efisiensi Pasar Modal Pada Indeks Saham Syariah Di Bursa Efek Indonesia”. Jurnal Katalogis. Vol 4. No 6. 2016.

Tandelin, Eduardus. 2010. "Potfolio dan Investasi. Teori dan Aplikasi". Kanisius, Edisi Pertama, Yogyakarta.

Umam, Khaerul, 2013. “ Pasar Modal Syariah”. Pustaka Setia, Bandung. Cetakan Pertama, Bandung.

https://finance.yahoo.com/ 